\title{
Sikap Toleransi Antaretnis
}

\author{
Erika Feri Susanto \& Anisia Kumala \\ Fakultas Psikologi Universitas Muhammadiyah Prof. Dr. Hamka \\ Kebayoran Baru, Jakarta Selatan. 12210 \\ erikaferisusanto@gmail.com, anisiakumala@gmail.com
}

\begin{abstract}
Indonesia is a country with diverse ethnic, ethnic and religious diversity, making Indonesia a multicultural country. This study aims to explore the relationship between the basic values of individuals with the attitude of interethnic tolerance in Indonesia. Individual basic values are defined as values that represent a person both in behavior and in acting. While tolerance can be interpreted as an attitude of mutual respect and mutual harmony in a difference between ethnicity, ethnicity and religion. The scale used in this study is the Portrait Values Questionnaire (PVQ) as a measure of individual basic values and The Tolerance Index (TI) as a measure of tolerance. This research method uses quantitative research methods. The sampling technique used was accidental sampling with respondents consisting of 79 people consisting of men and women aged 18-40 years. The results of this study indicate that there is a significant relationship between the variables of the basic value of individuals with an attitude of tolerance with a P-Value of $0.031(P<0.05)$ with a Pearson Correlation value of 0.244 which indicates a significant positive relationship between the basic values of individuals with an attitude of tolerance. The higher the basic value of the individual, the higher the tolerance attitude between ethnic groups.
\end{abstract}

Keywords: Individual basic values, tolerance, interethnicity

\begin{abstract}
Abstrak
Indonesia merupakan salah satu negara dengan keberagaman baik suku, etnis, maupun agama, sehingga menjadikan Indonesia sebagai negara yang multikultural. Penelitian ini bertujuan untuk mencari hubungan antara nilai dasar individu dengan sikap toleransi antaretnis di Indonesia. Nilai dasar individu diartikan sebagai nilai-nilai yang mewakili seorang pribadi baik dalam berperilaku maupun bertindak. Sedangkan toleransi dapat diartikan sebagai sikap saling menghargai dan saling menciptakan harmonisasi dalam sebuah perbedaan baik suku, antaretnis maupun agama. Adapun skala yang digunakan pada penelitian ini adalah Portrait Values Questionnaire (PVQ) sebagai alat ukur nilai dasar individu dan The Tolerance Index (TI) sebagai alat ukur toleransi. Metode penelitian ini menggunakan metode penelitian kuantitatif. Adapun teknik sampling yang digunakan adalah accidental sampling dengan responden terdiri dari 79 orang terdiri dari laki-laki dan perempuan berusia 18-40 tahun. Hasil penelitian ini menunjukan bahwa adanya hubungan yang signifikan antara variabel nilai dasar individu dengan sikap toleransi dengan $P$-Value sebesar $0,031(\mathrm{P}<0,05)$ dengan nilai Pearson Correlation sebesar 0,244 yang menunjukan adanya hubungan positif yang signifikan antara nilai dasar individu dengan sikap toleransi. Semakin tinggi nilai dasar individu maka semakin tinggi sikap toleransi antaretnis.
\end{abstract}

Kata Kunci: Nilai dasar individu, toleransi, antaretnis 


\section{Pendahuluan}

Bhineka Tunggal Ika merupakan semboyan dalam membentuk kesadaran akan persatuan dan kesatuan mengingat bangsa Indonesia memiliki dinamika budaya atau multikultural. Menurut Molan (2016) menjelaskan bahwa keberagaman yang ada di Indonesia merupakan wujud dari aspek dan fakta keanekaragaman budaya yang ditanggapi dan disikapi secara normatif. Perbedaan budaya tidak jarang dianggap sebagai salah satu masalah yang biasa muncul di dalam masyarakat. Konflik sosial yang timbul tidak jarang terjadi antar kaum minoritas dan kaum mayoritas yang menuntut hak dalam kesetaraan sebagai seorang makhluk sosial.

Keberagaman etnis di Indonesia menuntut masyarakat untuk cerdas dan bijak dalam menerima informasi yang beredar dengan mencari kebenarannya terlebih dahulu. Tidak jarang kesalahpahaman penerimaan informasi menjadi akar dari perselisihan yang terjadi antar etnis di Indoneisa. Pada tahun 2001 silam Indonesia digegerkan oleh konflik sampit atau tragedi sampit yang terjadi antaretnis Dayak dan Madura. Berdasarkan laman news.okezone.com menjelaskan bahwa konflik yang terjadi antara suku Dayak dan Madura banyak dugaan yang mencuat dimasyarakat, diantaranya adalah kasus pembunuhan hingga kasus pemerkosaan. Salah satu contoh kasus lain yang belum lama terjadi adalah mengenai sikap sentimen antaretnis yang terjadi pada akhir tahun 2018 dimana perselisihan terhadap etnis Tionghoa kembali merebak setelah munculnya kasus Uighur yang terjadi akibat dari persikusi yang dilakukan oleh pemerintah Cina. Permasalahan ini menimbulkan berbagai respon khususnya masyarakat pribumi yang kemudian dikhawatirkan akan kembali memancing kesenjangan diantara keduanya, mengingat pada tahun 1998 telah terjadi penjarahan dan kerusuhan yang menular kepada konflik antara etnis Tionghoa dan pribumi.

Dalam hal ini konsep keberagaman etnis/multikultural muncul sebagai upaya dalam membangun tatanan masyarakat yang memiliki ragam budaya dan sebuah kekhawatiran akan menimbulkan konflik-konflik yang bersifat destruktif sehingga akan merusak tatanan kehidupan di dalam masyarakat. Munculnya Undang Undang No 40 tahun 2008 tentang penghapusan diskriminasi ras dan etnis merupakan langkah yang dilakukan oleh pemerintah pusat demi menghilangkan kerisauan yang timbul diantara keduanya. Komitmen yang dilakukan pemerintah sebagai upaya untuk memberikan perlindungan serta kesetaraan dalam ruang lingkup hukum sehingga semua warga negara bebas dari diskriminasi ras dan etnis.

Perilaku manusia dipengaruhi oleh hubungan antar organisme dan lingkungannya, sehingga proses-proses dan dinamika psikologis yang mendasari perilaku (Irwanto, 2016). Adanya faktor ekternal dan internal membuat manusia terkadang sulit dalam menentukan perilaku mana yang baik dan buruk. Hal ini disebabkan karena dalam berperilaku manusia akan menampilkan perilaku yang memiliki makna bagi dirinya (Sutojo dan Hidayat, 2018). Begitu pula dengan cara seorang individu berperilaku dalam perbedaan yang ada di lingkungan sekitarnya. Perilaku saling menghargai dan menghormati dalam perbedaan dapat menciptakan efek positif yang baik dalam bermasyarakat. Dengan kata lain mereka memerlukan kesadaran akan nilai nilai yang ada di dalam diri mereka untuk menumbuhkan sikap toleransi demi menjaga persatuan dan kesatuan dari berbagai macam perbedaan baik budaya, etnis, ras, maupun agama.

\section{Toleransi}

Toleransi adalah sikap dari kesabaran, kelapangan dada (Echols dan Shadily, 1976). Toleransi harus didukung oleh cakrawala pengetahuan yang luas, bersikap terbuka, dialog, kebebasan berpikir dan beragama (Casram, 2016). Melalui pengetahuan yang luas maka cara padang akan suatu hal akan berbeda dengan demikian akan mempengaruhi sikap toleransi. Menurut Komlev dalam Belasheva dan Petrova (2016) toleransi berasal dari bahasa latin yaitu "tolerentia" yang berarti 
untuk mengatasi, untuk menanggung, untuk bertahan. Toleransi merupakan kelapangan dada kepada siapapun, membiarkan orang berpendapat atau berpendirian lain serta tidak mau mengganggu kebebasan berfikir dan berkeyakinan lain (Ali, 2006). Toleransi juga dapat diartikan sebagai sikap positif dalam menghargai orang lain dengan menggunakan kebebasan hak asasi sebagai manusia dan makhluk sosial. Dengan sikap saling menghargai dan menghormati maka akan tercipta suasana yang aman dan tentram serta meminimalisir perpecahan diantara minoritas dan mayoritas. Sikap toleransi merupakan harmoni dalam perbedaan (Svanberg, 2014).

Untuk itu dengan memiliki toleransi yang tinggi diharapkan mampu menciptakan sebuah tatanan kehidupan yang pluralisme dengan baik, saling menghargai dan menghormati akan perbedaan demi menjaga persatuan dan kesatuan Indonesia. Tetapi sebaliknya, jika tidak memiliki toleransi maka tidak menutup kemungkinan akan menyebabkan perilaku destruktif yang ada di dalam masyarakat yang akan mengancam persatuan dan kesatuan Indonesia. Istilah toleransi dapat menyiratkan sikap dari sebuah anggota terhadap kelompok sosial. Toleransi sosial digunakan untuk mengukur toleransi terhadap kaum minoritas (Svanberg, 2014). Hasil penelitian yang dilakukan oleh Juditha (2015) menunjukan bahwa jika di dalam kontak sosial terjadi konflik maka ada fungsi komunikasi antar etnis yang tidak dilakukan dengan baik.

Di dalam teori toleransi terdapat beberapa dimensi yaitu toleransi antaretnis, toleransi sosial dan toleransi dalam kepribadian (Sztejnberg dan Jasinnski, 2016). Dimensi antaretnis meliputi sikap terhadap perbedaan mencangkup kedalam kaum mayoritas dan minoritas baik ras maupun etnis, contohnya adalah saling memahami perbedaan baik dalam perbedaan warna kulit ataupun letak geografis. Dalam bermasyarakat tidak jarang perbedaan gaya bahasa menjadi salah satu faktor yang disalah artikan (Nugroho dkk, 2012). Selanjutnya ada dimensi toleransi sosial meliputi kontak sosial yang terjadi ditengah masyarakat akan sebuah perbedaan melalui pola keterbukaan kontak sosial sehingga menciptakan sebuah komunikasi antaretnis yang baik. Dan dimensi toleransi dalam kepribadian meliputi penggambaran mengenai realitas lingkungan yang berada pada sebuah kebudayaan yang multikultural, contohnya adalah sebuah perlakuan diantara kedua etnis yang saling menghakimi satu sama lain.

Keunikan dan ciri khas setiap manusia menjadi sebuah fakta di dalam bermasyarakat yang menimbulkan berbagai perbedaan budaya dan sosial. Faktor internal pada diri masyarakat menjadi kunci dalam terciptanya ketentraman di dalam bermasyarakat. Masyarakat dihadapkan kepada interaksi sosial yang multikultural sehingga kesadaran akan pemahaman keberagaman kontak sosial antar etnis perlu untuk ditanamkan. Sikap toleransi berkaitan dengan faktor internal dan eksternal yang bersentuhan langsung dengan anggota dan kelompok di dalam masyarakat. Maka akan terjadi interaksi antara individu dengan masyarakat sehingga menciptakan sebuah sistem nilai yang ada pada diri individu berhubungan erat dengan sistem nilai sosial budaya masyarakat (Sutojo dan Hidayat, 2018). Struktur individu terdiri dari nilai-nilai yang ada di dalam diri individu atau sebuah sikap individu berdasarkan nilai individunya. Dalam hal ini nilai bertugas sebagai pemberi arah dalam berperilaku.

\section{Nilai dasar individu}

Nilai adalah penghubung antara individu yang memberi nilai, dengan suatu keadaan atau objek dengan suatu ukuran tertentu, yang bersumber pada norma yang dimiliki bersama di dalam suatu masyarakat (Sutojo dan Hidajat, 2018). Nilai dapat diartikan sebagai norma yang diyakini yang disusun berdasarkan kepentingannya. Nilai adalah sebuah keyakinan seorang mengenai pilihan dalam bertindak. Hal ini menunjukan bahwa nilai merupakan pengarah prilaku yang ditimbulkan dari dalam diri individu yang kemudian akan memberikan pengalaman bagi individu tersebut. 
Nilai merupakan proses yang mengiringi dan menentukan semua perilaku yang ditimbulkan oleh manusia (Alisjahbana, 1986). Nilai berfungsi sebagai untuk mengarahkan tingkah laku individu dalam proses aktualisasi diri (Sutojo dan Hidajat, 2018). Hal ini menunjukan bahwa seorang individu bebas dalam memilih nilai-nilai dalam menyesuaikan keadaannya.

Nilai dapat dikatakan sebagai karakteristik yang muncul dan membentuk seorang individu sehingga menjadikan pribadi yang lebih baik. Nilai yang terdapat pada seorang individu akan membentuk dan bertransformasi menjadi pribadi yang diinginkan. Maka dengan ini nilai menjadikan seorang individu sebagai dasar dalam berprilaku.

Basic human value (nilai dasar individu) membahas mengenai nilai yang mendasari perilaku yang di kemukakan oleh Schwartz (2001). Pada penelitiannya didapati 10 nilai yang ada pada diri individu yang berlaku secara universal yaitu Universalism, Benevolence, Tradition, Conformity, Security, Power, Achievement, Hedonism, Stimulation, dan Self-Direction.

Di dalam penelitian Schwartz (2001) menjelaskan bahwa Power merupakan pencapaian status sosial, dan gengsi, kontrol atau dominasi berlebih pada orang lain. Contoh dari nilai ini adalah social power, authority dan wealth. Achievement merupakan penghargaan atas standar sosial. Contoh dari nilai ini adalah successful, capable, dan ambitious. Hedonism merupakan kesenangan terhadap diri sendiri, contoh dari nilai ini adalah pleasure dan enjoying life. Stimulation merupakan kegembiraan, kesenangan dan tantangan dalam hidup, contoh dari nilai ini adalah daring, varied life, dan exciting life. Self-direction merupakan pemikiran dan tindakan, baik dalam memilih, berkreatifitas dan lain-lain. Contoh dari nilai ini adalah creativity, curious dan freedom. Universalism merupakan pemahaman, apresiasi, toleransi, dan perlindungan. Contoh dari nilai ini adalah social justice, broad minded, dan equality protecting the environment. Benevolence merupakan peningkatan kesejahteraan individu, contoh dari nilai ini adalah helpful, honest, dan forgiving. Tradition merupakan rasa hormat, komitmen, dan menerima adat istiadat dan pemikiran yang ada pada budaya atau agama, contoh dari nilai ini adalah humble dan devout accepting my portion in life. Conformity merupakan menahan tindakan demi menjaga keseimbangan sosial, menjaga norma sosial. Contoh dari nilai ini adalah politeness, obedient honoring parents and elders. Security merupakan rasa aman, keharmonisan, kestabilan bermasyarakat baik dengan orang lain atau diri sendiri. Contoh dari nilai ini adalah national security, social order, dan clean. Schwartz dalam Lindeman dan Verkasalo (2005) membagi nilai menjadi 2 dimensi yaitu dimensi conservation versus openness to change berkaitan dengan konflik untuk mempertahankan status melalui kesesuaian dengan norma norma yang ada. Dimensi self-transcendence versus selfenhancement berkaitan dengan konflik terhadap kesejahteraan baik kepentingan terhadap orang lain ataupun individu. Berdasarkan pemaparan sebelumnya didapati bahwa kesepuluh nilai memberikan pengaruh besar dalam berperilaku dan bersikap.

Dalam penelitian yang dilakukan oleh Sibarani (2016) bahwa pembinaan nilai, sikap dan pandangan akan berpengaruh terhadap upaya dalam pencegahan potensi konflik antaretnis. Hal ini menunjukan bahwa ada sebuah pola yang menggambarkan sebuah keterkaitan antara karakteristik nilai dasar individu yang dapat mempengaruhi perilaku atau cara bertindak, dalam hal ini adalah sikap toleransi terhadap sebuah perbedaan atau sikap toleransi antar etnis. 


\section{Metode}

\section{Partisipan}

Partisipan penelitian ini sebanyak 79 orang yang berdomisili di daerah Jakarta dan sekitaranya dengan rentang usia 18-40 tahun. Teknik sampling yang digunakan pada penelitian ini adalah accidental sampling.

\section{Desain}

Penelitian ini dilakukan dengan pendekatan kuantitatif. Pendekatan yang dilakukan dalam penelitian ini adalah pendekatan kuantitatif. Pendekatan kuantitatif adalah data yang didapat akan dikuantifikasikan sesuai dengan bobot jawaban dari responden penelitian (El Hafiz, 2013). Penelitian ini memberikan gambaran keterkaitan antar fenomena dengan menggunakan penyebaran skala kuisioner sebagai alat ukur dalam penelitian ini. Penelitian ini menggunakan dua alat ukur yaitu:

1. Portrait Values Questionnaire (PVQ) yang dikembangkan oleh Schwartz (2001) untuk mengukur nilai dasar individu dengan nilai reliabilitas sebesar 0,937 terdiri dari 39 item.

2. The Tolerance Index (TI) dikembangkan oleh Sztejnberg dan Jasinnski (2016) untuk mengukur toleransi dengan nilai realibilitas sebesar 0,730 terdiri dari 14 item.

\section{Teknik Analisis}

Pengolahan data yang dilakukan oleh peneliti adalah dengan menggunakan program SPSS for windows version 23.0, sedangkan teknik analisa data yang digunakan pada penelitian ini adalah analisa correlation karena terdapat 2 variabel yang digunakan dan ingin melihat hubungannya.

Tabel 1 correlation antara nilai dasar individu dengan toleransi

\begin{tabular}{|ll|r|r|}
\multicolumn{2}{|c|}{ Correlations } \\
\hline & toleransi & $\begin{array}{c}\text { nilaidasarPV } \\
\text { Q }\end{array}$ \\
\hline toleransi & Pearson Correlation & 1 & $.244^{*}$ \\
& Sig. (2-tailed) & & .031 \\
& $\mathrm{~N}$ & 79 & 79 \\
\hline nilaidasarPVQ & Pearson Correlation & $.244^{*}$ & 1 \\
& Sig. (2-tailed) & .031 & \\
& $\mathrm{~N}$ & 79 & 79 \\
\hline
\end{tabular}

*. Correlation is significant at the 0.05 level (2-tailed).

\section{Hasil Penelitian}

Dari analisa data yang dilakukan dengan SPSS version 23.0 pada tabel 1 menunjukan bahwa nilai dasar individu memiliki hubungan positif signifikan terhadap sikap toleransi dengan nilai Pearson Correlation sebesar 0,244 dengan nilai signifikansi 0,031 ( $<<0,05)$. Yang berarti semakin tinggi nilai dasar individu maka akan semakin tinggi sikap toleransinya. 


\section{Pembahasan}

Hasil penelitian yang diperoleh berdasarkan korelasi Pearson mengungkapkan bahwa adanya hubungan signifikan yang positif antara nilai dasar individu dengan sikap toleransi dengan nilai Pearson Correlation sebesar 0,244 dengan nilai signifikansi $0,031 \quad(\mathrm{P}<0,05)$. Hal ini mengindetifikasikan bahwa faktor internal dalam diri memiliki hubungan terhadap perilaku yang keluar pada diri seseorang. Penelitian ini juga didukung dengan penelitian yang telah dilakukan oleh Ardiansyah (2010) mengenai konflik yang antar etnis tidak akan terjadi jika kelompok etnis saling memiliki kesadaran dan sikap positif antara satu dengan yang lainnya, maka hubungan antar etnis cenderung diwarnai oleh rasa keguyuban dan kerukunan yang saling menguatkan, sehingga bisa menjadi modal utama untuk mencapai resolusi konflik antar etnis. Dengan menanamkan kesadaran dan sikap positif dalam diri maka akan terbentuk perilaku positif di dalam bermasyarakat.

Di dalam penelitian ini terdapat beberapa keterbatas dalam penelitian ini. Pertama, kontrol penelitian kurang ketat. Peneliti hanya mengontrol jenis kelamin, usia dan status (bekerja/tidak bekerja), maka dari itu dapat ditambahkan keterangan asal etnis/suku. Tujuannya agar dapat mengontrol apakah subyek yang mengisi kuisioner ini sudah benar. Kedua, jumlah sampel yang masih relatif kecil sehingga hasil penelitian kurang menggambarkan kondisi populasinya.

Kesimpulan yang didapat dari penelitian ini bahwa nilai dasar individu memiliki hubungan terhadap sikap toleransi dengan nilai Pearson Correlation sebesar 0,244 dengan nilai signifikansi $0,031(\mathrm{P}<0,05)$. Hal ini menunjukan adanya hubungan positif signifikan antara nilai dasar individu dengan sikap toleransi. Yang berarti semakin tinggi nilai dasar individu maka akan semakin tinggi sikap toleransinya.

Dalam penelitian ini hanya melihat etnis secara general, artinya semua etnis yang ada di Indonesia menjadi fokus utamanya maka dari itu disarankan untuk lebih melihat kepada lebih spesifik kapada salah satu etnis yang ada di Indonesia. Saran lain yang dapat dilakukan adalah dengan menggunakan variabel lain yang berkaitan dengan variabel toleransi seperti variabel religiusitas, variabel kepribadian yang kemungkinan dapat berhubungan dengan sikap toleransi.

Dengan adanya penelitian mengenai hubungan antara nilai dasar individu dengan toleransi, diharapkan penanaman nilai dasar individu dilakukan sedini mungkin. Hal ini bermanfaat untuk meningkatkan sikap toleransi dengan pengembangan sikap dan perilaku yang berorientasi kepada nilai pribadi.

\section{Daftar Pustaka}

Ali, Muhammad. (2006). Kamus Lengkap Bahasa Indonesia Moderen. Jakarta: Pustaka Amani.

Alisjahbana, T. S. (1986). Antropologi Baru, Nilai-Nilai sebagai Tenaga Integrasi Dalam Pribadi, Masyarakat, Dan Kebudayaan. Jakarta: PT. Dian Rakyat.

Ardiansyah. S. I. (2010). Konflik Etnis Samawa dengan Etnis Bali: Tinjauan Sosial Politik dan Upaya Resolusi Konflik. Universitas Samawa. Volume 23, Nomor 4 Hal: 286-292.

Belasheva, I. V dan Petrova. E. F. (2016). Psychological Stability of a Personality and Capability of

Tolerant Interaction as Diverse Manifestations of Tolerance. International Journal of Environmental \& Science Education 2016, Vol. 11, No. 10, 3367-3384.

Casram. (2016). Membangun Sikap Toleransi Beragama Dalam Masyarakat Plural. Jurnal Ilmiah Agama dan Sosial Budaya Vol 1, No 2 Juli 2016: 187-198. 
Echols. J. M., dan Shadily. H. (1975). Kamus Inggris Indonesia. Jakarta: PT Gramedia Pustaka Utama.

Irwanto. (2016). Psikologi Umum Buku Panduan Mahasiswa. Jakarta: PT Prenhallindo.

Juditha, Cristiany. (2015). Stereotip dan Prasangka dalam Konflik Etnis Tionghoa dan Bugis Makasar. Jurnal Ilmu Komunikasi vol 12, no. 1, Juni 2015: 87-104.

Lindeman, M. \& Verkasalo, M. (2005). Measuring values with the Short Schwartz's Value Survey. Journal of Personality Assessment, 85(2),170-178.

Molan, Benyamin. (2016). Multikulturalisme Cerdas Membangun Hidup Bersama yang Stabil dan Dinamis. Jakarta: PT Indeks.

Nugroho A. B, Lestari P dan Wiendijarti I. (2012). Pola Komunikasi Antarbudaya Batak dan Jawa di Yogyakarta. Jurnal Komunikasi, Volume 1, Nomor 5, Juli 2012.

Sibarani, Berlin. (2016). Bahasa, Etnisitas Dan Potensinya Terhadap Konflik. Jurnal Title. pp. 1-11.

Sutojo, N. N dan Hidayat L. L. (2018). Etika Psikologi, Menilik Nurani Psikologi Indonesia. Jakarta: PT Kompas Media Nusantara.

Svanberg, Lisa. (2014). Tolerance of Diversity and the Influence of Happiness. Bachelor Thesis in Economics. Karlstad Business School.

Sztejnberg. A and Jasinnski. T. L. (2016). Measurement of the tolerance general level in the higher education students. International Journal of Latest Research in Humanities and Social Science (IJLRHSS). Volume 01 - Issue 04.

Shalom H. Schwartz, Gila Melech, Arielle Lehmann, Steven Burgess, Mari Harris and Vicki Owens. (2001) Extending the Cross-Cultural Validity of the Theory of Basic Human Values with a Different Method of Measurement. Journal of Cross-Cultural Psychology 2001 32: 519.

Undang-Undang Republik Indonesia No. 40 Tahun 2008 Tentang Penghapusan Diskriminasi dan Ras. Diakses pada 26 Januari 2019 pada pukul 14.48 di http://referensi.elsam.or.id 